\title{
Treatment of Acute Puerperal Metritis with Flunixin Meglumine in Addition to Antibiotic Treatment
}

\author{
M. Drillich, ${ }^{1}$ D. Voigt, D. Forderung, and W. Heuwieser \\ Clinic for Animal Reproduction, Faculty of Veterinary Medicine, Free University of Berlin, 14163, Germany
}

\begin{abstract}
The objective of this field trial was to evaluate effects of a single administration of $2.2 \mathrm{mg} / \mathrm{kg}$ of body weight (BW) of flunixin meglumine (FM) in addition to a systemic antibiotic treatment in cows with acute puerperal metritis (APM). Outcome variables tested were proportion of cows with a fever, prevalence of chronic endometritis 18 to 22 and 32 to $35 \mathrm{~d}$ in milk (DIM), and reproductive performance measures in the current lactation. In addition, serum concentrations of haptoglobin and fibrinogen were analyzed. Daily milk yield within 6 $\mathrm{d}$ after the first treatment was recorded. Cows were examined 4 to 5 DIM by rectal palpation and vaginoscopy, and rectal temperature was measured. Fetid vulvar discharge and a body temperature $\geq 39.5^{\circ} \mathrm{C}$ were signs of APM. Cows with APM were treated in the reference group with $1.0 \mathrm{mg} / \mathrm{kg}$ of BW of ceftiofur on 3 to 5 consecutive days $(\mathrm{CEF}, \mathrm{n}=119)$. In the study group, cows received the same antibiotic treatment as in $\mathrm{CEF}$ and $2.2 \mathrm{mg} / \mathrm{kg}$ of BW of FM on treatment d 1 (CEF + FM, $\mathrm{n}=119$ ). Blood samples were collected 4,6 , and 10 DIM and analyzed for concentrations of haptoglobin and fibrinogen. A group of cows without APM remained untreated and served as controls $(n=9)$. There were no significant differences between $\mathrm{CEF}$ and $\mathrm{CEF}+\mathrm{FM}$ in the proportion of cows with fever $1 \mathrm{~d}$ after the first treatment ( 33.6 vs. $46.2 \%$ ), milk yield per milking 10 DIM (7.5 \pm 0.3 vs. $7.6 \pm 0.3 \mathrm{~kg}$ in primiparous, $9.6 \pm 0.4$ vs. $10.6 \pm 0.4 \mathrm{~kg}$ in multiparous cows), prevalence of chronic endometritis 32 to 35 DIM (64.3 vs. $52.2 \%)$, and in reproductive performance (31.5 vs. $34.3 \%$ conception to first AI, 58.0 vs. $54.6 \%$ pregnancy rate, $107.8 \pm 36.9$ vs. $101.6 \pm 41.4 \mathrm{~d}$ open). Compared with the control, $\mathrm{CEF}$ and CEF + FM had significantly greater concentrations of haptoglobin $(1.1 \pm 0.28$ vs. $1.9 \pm 0.06$ and $1.8 \pm$ $0.07 \mathrm{mg} / \mathrm{mL}$ at 4 DIM; $0.3 \pm 0.15$ vs. $1.1 \pm 0.06$ and 1.2 $\pm 0.07 \mathrm{mg} / \mathrm{mL}$ at $10 \mathrm{DIM})$ and fibrinogen $(2.2 \pm 0.17 \mathrm{vs}$. $3.9 \pm 0.14$ and $3.7 \pm 0.13 \mathrm{~g} / \mathrm{L}$ at $4 \mathrm{DIM} ; 1.9 \pm 0.1$ vs. 2.6
\end{abstract}

Received January 24, 2007.

Accepted April 11, 2007.

${ }^{1}$ Corresponding author: author@bestandsbetreuung.de \pm 0.1 and $3.0 \pm 0.13 \mathrm{~g} / \mathrm{L}$, respectively, at $10 \mathrm{DIM}$ ) on all test days. The additional treatment with FM had no effect on these acute phase proteins. In conclusion, the single administration of $2.2 \mathrm{mg} / \mathrm{kg}$ of BW of FM in addition to a systemic antibiotic treatment of cows having APM did not result in beneficial effects on clinical cure, milk yield within $6 \mathrm{~d}$ after the first treatment, or reproductive performance.

Key words: acute puerperal metritis, flunixin meglumine, haptoglobin, fibrinogen

\section{INTRODUCTION}

Acute puerperal metritis (APM), which is also called postpartum metritis, toxic puerperal metritis, or septic metritis, occurs within the first $10 \mathrm{~d}$ after parturition. It is characterized by fetid, watery, and reddish-brown to purulent vulvar discharge and fever $\geq 39.5^{\circ} \mathrm{C}$ (Sheldon et al., 2006). Body temperature that can be regarded as fever varies from $39.2^{\circ} \mathrm{C}$ (Smith et al., 1998) to $39.5^{\circ} \mathrm{C}$ (Stevens et al., 1995; Drillich et al., 2001, 2003) and $39.7^{\circ} \mathrm{C}$ (Dinsmore et al., 1996; Sheldon et al., 2006). The palpation of the uterus per rectum reveals an enlarged and flaccid uterus.

The treatment of APM is based on the local or systemic use of antibiotics. The use of a systemic antibiotic treatment with ceftiofur (CEF) has been reported in several studies (Smith et al., 1998; Drillich et al., 2001; Zhou et al., 2001). In addition to antibiotics, treatment with nonsteroidal antiinflammatory drugs (NSAID) has been discussed (Odensvik and Fredriksson, 1993). Amiridis et al. (2001) treated 128 cows with puerperal metritis 5 to $8 \mathrm{~d}$ after calving with $2.2 \mathrm{mg} / \mathrm{kg}$ of BW of flunixin meglumine (FM) intravenously. On the first 2 d of treatment, cows received FM twice daily, on the subsequent $2 \mathrm{~d}$, once daily. Compared with 131 salinetreated control cows, treatment with FM accelerated the uterine involution and shortened the calving-tofirst-estrus interval. In contrast, Königsson et al. (2001) did not find an effect of FM on uterine involution or recovery from uterine infection. Data on reproductive performance were not given. In that study, FM was administered orally, twice daily on $\mathrm{d} 3$ to 6 or 11 to 14 postpartum. 
Acute phase proteins have been suggested as a physiological response on trauma or infection to prevent tissue damage, to destroy bacteria, and to activate repair processes (Baumann and Gauldie, 1994). Haptoglobin $(\mathbf{H p})$ and fibrinogen $(\mathbf{F b}), 2$ acute phase proteins, were reported as indicators for acute inflammatory processes in cattle (Alsemgeest et al., 1994; Hirvonen et al., 1999; Schonfelder et al., 2005). In a study using calves, Hp concentration increased $24 \mathrm{~h}$ after artificial infection, with a peak at $72 \mathrm{~h}$ (Cheryk et al., 1998). Schonfelder et al. (2005) demonstrated increasing Hp concentrations in cows with caesarean section compared with normal deliveries after $5 \mathrm{~d}$ postpartum. In cows with caesarean section after uterine torsion, Hp was significantly increased before surgery. Smith et al. (1998) found decreasing $\mathrm{Hp}$ concentrations in cows with toxic puerperal metritis from 13.4 to $20.0 \mathrm{mg} / \mathrm{dL}$ at d 1 to 4.25 to $9.79 \mathrm{mg} / \mathrm{dL}$ at d 5 after 3 different antibiotic treatment regimes. The decrease of acute phase proteins in serum within $4 \mathrm{wk}$ after calving was demonstrated by Sheldon et al. (2001).

The objective of this field trial was to evaluate effects of a single administration of $2.2 \mathrm{mg} / \mathrm{kg}$ of $\mathrm{BW}$ of FM in addition to a systemic antibiotic treatment in cows with APM. Clinical postpartum measures (body temperature, $\mathrm{Hp}$ and $\mathrm{Fb}$ concentrations, daily milk yield, prevalence of chronic endometritis 18 to 22 and 32 to 35 DIM) and reproductive performance in the current lactation were compared between APM cows that did or did not receive FM.

\section{MATERIALS AND METHODS}

The study was conducted from March 2001 to May 2002 on a dairy farm in Saxony-Anhalt, Germany. The participating farmer and the local veterinarian were informed about all relevant characteristics of the study and agreed with the study design. For the study, an experimental test permit was obtained from responsible local authorities.

A total of 1,000 Holstein cows were housed in freestall barns with rubber mats and slotted floors. Approximately $7 \mathrm{~d}$ before expected calving, cows were housed in a free-stall barn with straw bedding. Cows were milked 3 times daily in a rotary parlor with 42 stalls. Herd average milk yield was $9,000 \mathrm{~kg}$ per lactation.

All cows were examined 4 to $5 \mathrm{~d}$ postpartum for signs of APM. The examination included an evaluation of the general condition of the cow, rectal temperature, vaginal inspection via speculum, and examination of the uterus per rectal palpation. Cows having fetid, reddish-brown, watery vulval discharge in combination with a rectal temperature $\geq 39.5^{\circ} \mathrm{C}$ (fever) were charac- terized as having APM. Day of examination was defined as d 0 .

Cows with APM were assigned in an alternating order to groups. In group 1, cows received a systemic antibiotic treatment of $1 \mathrm{mg} / \mathrm{kg}$ of BW of CEF (Excenel RTU, Pfizer Animal Health, Karlsruhe, Germany) administered systemically on 3 consecutive days (d 0 , d $1, \mathrm{~d} 2$ ). Cows with a fever on $\mathrm{d} 3$ received $1 \mathrm{mg} / \mathrm{kg}$ of BW of CEF for 2 additional days. In the case of a fever after $5 \mathrm{~d}$ of treatment with $\mathrm{CEF}$, cows received an escape therapy (i.e., a different systemic antibiotic chosen by the local veterinarian). Group 2 cows received the antibiotic treatment regimen as described for $\mathrm{CEF}$ cows. In addition, all CEF + FM cows received 1 single intravenous treatment with $2.2 \mathrm{mg} / \mathrm{kg}$ of BW of FM (Finadyne, Essex Tierarznei, Munich, Germany) on d 0 . In both groups, rectal temperature was measured for $7 \mathrm{~d}$ after enrollment.

In Germany, FM is approved in a dosage of $2.2 \mathrm{mg} /$ $\mathrm{kg}$ of BW for the treatment of acute pneumonia in cattle (Friton et al., 2004). Thus, the treatment of APM with FM is regarded as extra label drug use. Cows that received antiinflammatory or antibiotic drugs for purposes not related to the study (e.g., acute mastitis) were excluded from the trial. Considering the potentially lifethreatening character of toxic puerperal metritis (Eiler, 1997), no untreated APM cows were included as controls.

Blood samples were collected from the coccygeal vein on $\mathrm{d}$ 0, 2, and 6 from CEF and CEF + FM cows and from cows without APM (control group). For the analysis of $\mathrm{Hp}$ and $\mathrm{Fb}$, blood was collected into EDTA- and citratecoated tubes, respectively. Thereafter, samples were centrifuged at $3,500 \times \mathrm{g}$ for $15 \mathrm{~min}$. Plasma was stored at $-20^{\circ} \mathrm{C}$ in 2 aliquots of 2 to $3 \mathrm{~mL}$ each until analysis. Haptoglobin was measured by PhaseRange Haptoglobin Assay (BioRepair, Sinsheim, Germany) and analyzed by photometric extinction. Fibrinogen was quantified with a coagulometer (Biomatic 2000, Dade Behring, Eschborn, Germany).

All APM cows were examined from 18 to 24 DIM and again from 32 to 38 DIM by rectal palpation of the uterus and by vaginoscopy for (muco-)purulent vaginal discharge as a sign of chronic endometritis. After each examination, all cows were treated with $25 \mathrm{mg}$ of $\mathrm{PGF}_{2 \alpha}$ intramuscularly (Dinolytic, Pfizer Animal Health) to support the involution of the uterus (Nakao et al., 1997). All treatments were documented on case report forms, which remained on farm to ensure that all cows received the correct treatments each day. At the end of the study, case report forms were checked for compliance and plausibility of the data. Cows with incomplete treatments or other deviations from the treatment protocol were retrospectively deleted. 
For all cows, the voluntary waiting period was set at 60 DIM. Cows observed in estrus were AI. Pregnancy diagnosis was performed by an experienced AI technician from 42 to $49 \mathrm{~d}$ after AI. Cows not inseminated by 80 DIM or identified as not pregnant were examined by vaginoscopy and rectal palpation of the uterus and the ovaries for abnormalities and treated according to the diagnosis. Cows with a palpable corpus luteum received $\mathrm{PGF}_{2 \alpha}$ to induce estrus. No timed breeding protocols were used.

Reproductive performance was characterized by days to first AI, days to pregnancy (days open), conception to first AI, total conception to AI (number of cows pregnant divided by total number of inseminations $\times 100$ ), pregnancy rate (number of cows pregnant by 200 DIM divided by number of cows enrolled $\times 100$ ), and cows culled. Cows not pregnant by 200 DIM were regarded as open even if they remained in the herd and conceived later in lactation.

\section{Statistical Analyses}

Data were analyzed using SPSS for Windows (Version 12.0, SPSS Inc. Munich, Germany). Proportions of cows with a fever and with chronic endometritis, as well as conception rates and proportions of cows inseminated, pregnant, and culled were compared between treatments (CEF vs. CEF + FM) by using $\chi^{2}$ analyses. Days to first service and days open were compared by Mann-Whitney U test. Survival analysis for days to culling was performed by using Cox-regression, censoring cows that were not culled. For survival analysis, treatment group (CEF, $\mathrm{CEF}+\mathrm{FM})$ and parity (multiparous, primiparous) were included as covariates.

Haptoglobin and $\mathrm{Fb}$ concentrations at $\mathrm{d}$ 0, 2, and 6 as well as milk yield from d 0 to $\mathrm{d} 6$ were compared in a general linear model for repeated measurements. For analysis of $\mathrm{Hp}$ and $\mathrm{Fb}$, group (CEF, CEF + FM, control), and for milk yield, group (CEF, CEF + FM) and parity (primiparous, multiparous) were fixed factors in the analyses. Level of significance for all statistical analyses was $\alpha=0.05$.

\section{RESULTS}

\section{APM, Chronic Endometritis}

A total of 1,299 cows and heifers were calved during the study period. The prevalence of APM at d 0 was $18.3 \%$. In groups CEF $(\mathrm{n}=119)$ and CEF + FM ( $\mathrm{n}=$ 119), the proportion of primiparous cows was 54.6 and $51.3 \%$, respectively. The proportion of cows having retained placenta was 21.8 and $24.4 \%$ in $\mathrm{CEF}$ and $\mathrm{CEF}$ $+\mathrm{FM}$, respectively.
Table 1. Clinical traits in cows having acute puerperal metritis

\begin{tabular}{|c|c|c|c|c|}
\hline \multirow[b]{3}{*}{ Trait } & \multicolumn{4}{|c|}{ Treatment $^{1}$} \\
\hline & \multicolumn{2}{|c|}{$\mathrm{CEF}$} & \multicolumn{2}{|c|}{$\mathrm{CEF}+\mathrm{FM}$} \\
\hline & $\mathrm{n}$ & $\%$ & $\mathrm{n}$ & $\%$ \\
\hline Fever at d 1 & $40 / 119$ & 33.6 & $55 / 119$ & 46.2 \\
\hline Fever at d 3 & $24 / 118$ & 20.3 & $26 / 119$ & 21.8 \\
\hline Fever at d 6 & 14/118 & 11.9 & 14/119 & 11.8 \\
\hline Endometritis 18 to $22 \mathrm{DIM}^{2}$ & $100 / 107$ & 93.5 & $109 / 115$ & 94.8 \\
\hline Endometritis 32 to $35 \mathrm{DIM}^{3}$ & $63 / 98$ & 64.3 & $59 / 113$ & 52.2 \\
\hline
\end{tabular}

${ }^{1} \mathrm{CEF}=1 \mathrm{mg} / \mathrm{kg}$ of $\mathrm{BW}$ of ceftiofur once daily for 3 consecutive days. When fever was present after $3 \mathrm{~d}$, treatment was continued for 2 more days; $\mathrm{CEF}+\mathrm{FM}=1 \mathrm{mg} / \mathrm{kg}$ of BW of ceftiofur for 3 to 5 consecutive days and $2.2 \mathrm{mg} / \mathrm{kg}$ of $\mathrm{BW}$ of flunixin meglumine at $\mathrm{d} 1$.

${ }^{2}$ Findings of 3 cows in group CEF were not recorded.

${ }^{3}$ Findings of 3 cows in group CEF and 5 cows in group CEF + FM were not recorded.

Table 1 presents clinical traits for $\mathrm{CEF}$ and $\mathrm{CEF}+$ FM cows. No differences were found between the groups for the proportion of cows with a fever at $d 1,3$, and 6 and for the proportion of cows with chronic endometritis 18 to 22 DIM and 32 to 35 DIM $(P>0.05)$.

\section{$\mathrm{Hp}$ and $\mathrm{Fb}$}

The general linear model revealed that $\mathrm{Hp}$ and $\mathrm{Fb}$ concentrations were greater in CEF and CEF + FM than in the control $(P<0.05)$. No differences were found between CEF and CEF + FM $(P>0.05)$. In all groups, a significant decrease in $\mathrm{Hp}$ and $\mathrm{Fb}$ concentrations was found from d 0 to d $6(P<0.05)$. Parity did not influence $\mathrm{Hp}$ or $\mathrm{Fb}$ concentrations $(P>0.05)$.

Concentrations of $\mathrm{Hp}$ and $\mathrm{Fb}$ at $\mathrm{d} 0,2$, and 6 are presented in Figures 1 and 2, respectively. Mean Hp concentration at d 0 was $1.9 \pm 0.06,1.8 \pm 0.07$, and $1.1 \pm 0.28 \mathrm{mg} / \mathrm{mL}$ in $\mathrm{CEF}, \mathrm{CEF}+\mathrm{FM}$, and control, respectively. In all groups, Hp concentrations were less at d $6(1.1 \pm 0.06,1.2 \pm 0.07$, and $0.3 \pm 0.15 \mathrm{mg} / \mathrm{mL}$ in $\mathrm{CEF}, \mathrm{CEF}+\mathrm{FM}$, and control, respectively). Mean Fb concentration at $\mathrm{d} 0$ was $3.9 \pm 0.14,3.7 \pm 0.13$, and 2.2 $\pm 0.17 \mathrm{~g} / \mathrm{L}$ in $\mathrm{CEF}, \mathrm{CEF}+\mathrm{FM}$, and control, respectively. Fibrinogen concentrations were less at $\mathrm{d} 6$ in all groups $(2.6 \pm 0.1,3.0 \pm 0.13$, and $1.9 \pm 0.1 \mathrm{~g} / \mathrm{L}$ in $\mathrm{CEF}, \mathrm{CEF}+$ FM, and control, respectively).

\section{Reproductive Performance}

Table 2 shows reproductive performance traits of CEF and CEF + FM cows. No differences were found between the groups for any of the calculated traits $(P$ $>0.05)$. Cox regression revealed no effect of treatment group on the hazard ratio (HR) of culling $(P>0.05$, $\mathrm{HR}=1.45,95 \%$ confidence interval $=0.82$ to 2.55 ). Multiparous cows showed a tendency toward a greater 


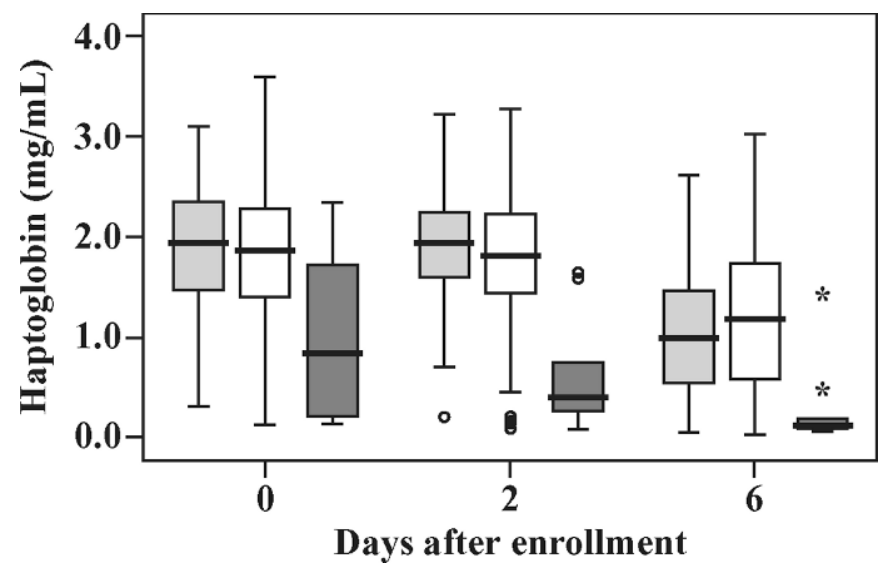

Figure 1. Concentrations of haptoglobin in plasma $(\mathrm{mg} / \mathrm{mL})$ in CEF (light-shaded boxplot, $\mathrm{n}=117$ ), $\mathrm{CEF}+\mathrm{FM}$ (white boxplot, $\mathrm{n}=$ 118), and control (dark-shaded boxplot, $\mathrm{n}=9$ ) at d 0,2 , and 6 . CEF $=$ cows with acute puerperal metritis treated with $1 \mathrm{mg} / \mathrm{kg}$ of $\mathrm{BW}$ of ceftiofur once daily for 3 consecutive days. When fever was present after $3 \mathrm{~d}$, treatment was continued for 2 more days; $\mathrm{CEF}+\mathrm{FM}=$ cows with acute puerperal metritis treated with $1 \mathrm{mg} / \mathrm{kg}$ of BW of ceftiofur for 3 to 5 consecutive days and $2.2 \mathrm{mg} / \mathrm{kg}$ of BW of flunixin meglumine at $\mathrm{d} 1.0=$ outliers; $*$ extremes.

hazard for culling than primiparous cows $(P=0.053$, $\mathrm{HR}=1.76,95 \%$ confidence interval $=0.99$ to 3.11 )

\section{Milk Yield}

Complete milk yield data from d 0 to 6 were obtained from $115 \mathrm{CEF}$ and $115 \mathrm{CEF}+\mathrm{FM}$ cows. In primiparous

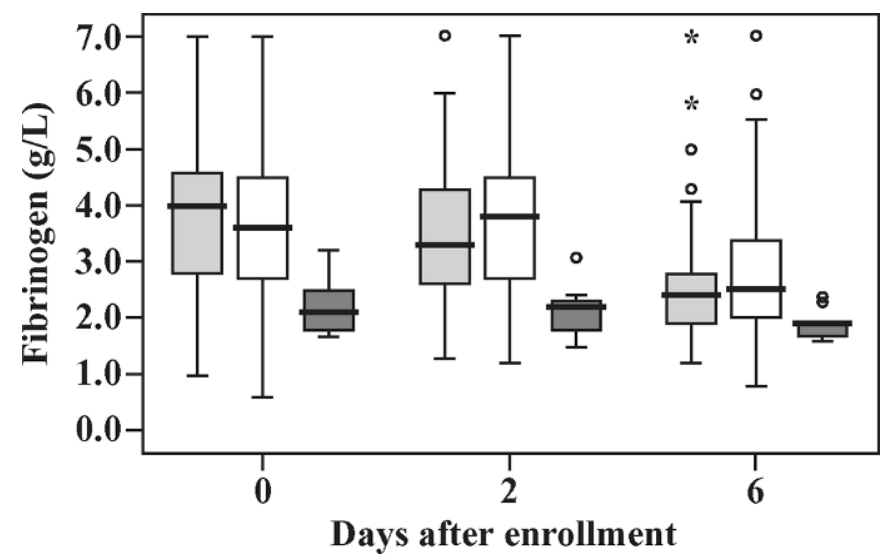

Figure 2. Concentrations of fibrinogen in plasma $(\mathrm{g} / \mathrm{L})$ in $\mathrm{CEF}$ (light-shaded boxplot, $\mathrm{n}=117$ ), $\mathrm{CEF}+\mathrm{FM}$ (white boxplot, $\mathrm{n}=118$ ), and control (dark-shaded boxplot, $\mathrm{n}=9$ ) at $\mathrm{d} 0,2$, and 6 . $\mathrm{CEF}=$ cows with acute puerperal metritis treated with $1 \mathrm{mg} / \mathrm{kg}$ of BW of ceftiofur once daily for 3 consecutive days. When fever was present after $3 \mathrm{~d}$, treatment was continued for 2 more days; $\mathrm{CEF}+\mathrm{FM}=$ cows with acute puerperal metritis treated with $1 \mathrm{mg} / \mathrm{kg}$ of BW of ceftiofur for 3 to 5 consecutive days and $2.2 \mathrm{mg} / \mathrm{kg}$ of BW of flunixin meglumine at d $1.0=$ outliers; $*$ extremes.
Table 2. Reproductive performance traits during 200 DIM for cows having acute puerperal metritis

\begin{tabular}{lcc}
\hline & \multicolumn{2}{c}{ Treatment $^{1}$} \\
\cline { 2 - 3 } Trait & CEF & CEF + FM \\
\hline No. of cows & 119 & 119 \\
Cows inseminated (\%) & 74.8 & 85.7 \\
Days to first AI (d \pm SEM) & $76.8 \pm 20.1$ & $80.1 \pm 24.2$ \\
Conception to first AI (\%) & 31.5 & 34.3 \\
Total conception (\%) & 34.8 & 31.3 \\
Pregnancy rate (\%) & 58.0 & 54.6 \\
Days open (d \pm SEM) & $107.8 \pm 36.9$ & $101.6 \pm 41.4$ \\
Cows culled (\%) & 23.5 & 17.6 \\
\hline
\end{tabular}

${ }^{1} \mathrm{CEF}=1 \mathrm{mg} / \mathrm{kg}$ of $\mathrm{BW}$ of ceftiofur once daily for 3 consecutive days. When fever was present after $3 \mathrm{~d}$, treatment was continued for 2 more days; $\mathrm{CEF}+\mathrm{FM}=1 \mathrm{mg} / \mathrm{kg}$ of BW of ceftiofur for 3 to 5 consecutive days and $2.2 \mathrm{mg} / \mathrm{kg}$ of $\mathrm{BW}$ of flunixin meglumine at $\mathrm{d} 1$.

cows, milk yield increased from $5.8 \pm 0.3 \mathrm{~kg}$ and $5.7 \pm$ $0.3 \mathrm{~kg}$ per milking at $\mathrm{d} 0$ to $7.5 \pm 0.3$ and $7.6 \pm 0.3 \mathrm{~kg}$ per milking at $\mathrm{d} 6$ in CEF and CEF + FM, respectively. In multiparous cows, milk yield increased from $8.0 \pm$ 0.3 and $8.6 \pm 0.4 \mathrm{~kg}$ per milking at $\mathrm{d} 0$ to $9.6 \pm 0.4$ and $10.6 \pm 0.4 \mathrm{~kg}$ per milking at $\mathrm{d} 6$ in $\mathrm{CEF}$ and $\mathrm{CEF}+\mathrm{FM}$, respectively. Milk yield per milking was influenced by parity $(P<0.05)$ but not by treatment group $(P>0.05)$.

\section{DISCUSSION}

The rationale for the treatment of APM with FM was the hypothesis that the antiinflammatory potency of NSAID improves clinical cure. Improved cure rates should result in higher milk yield and increased reproductive performance. The results of our study reject this hypothesis for the treatment of APM with a single administration of $2.2 \mathrm{mg} / \mathrm{kg} \mathrm{BW}$ of FM. Clinical measures (temperature, prevalence of chronic endometritis) and concentrations of acute phase proteins did not result in differences between CEF + FM and CEF. Thus, differences in reproductive performance were not expected and were not found. This is evident only for a single administration of FM. Whether a repeated treatment (e.g., for $3 \mathrm{~d}$ or multiple per day) would be beneficial to the course of the inflammation and clinical cure needs further investigation. Survival analysis did not reveal any effect of treatment on the hazard of culling. Yet, a noticeable increase in the proportion of cows culled in CEF was found near 20 DIM. Reasons for culling within 20 DIM showed a large variation (data not shown). Furthermore, because of the limited number of cows, this difference should not be overinterpreted. Milk yield was lower in cows with acute metritis (Montes and Pugh, 1993; Smith et al., 1998), dystocia, and assisted calving (Tenhagen et al., 1999). For cows with retention of the fetal membranes, another predisposing factor for APM, the effect on milk yield is contro- 
versial (Rajala and Gröhn, 1998). Compared with group $\mathrm{CEF}$, cows in group CEF + FM did not benefit from an additional treatment with FM in milk production within $6 \mathrm{~d}$ after the first treatment. Unfortunately, no milk yield data of control cows were available. Thus, long-term effects on milk yield beyond $6 \mathrm{~d}$ of the treatment with FM are pure speculation.

The differences in $\mathrm{Hp}$ and $\mathrm{Fb}$ concentrations in cows with and without APM (CEF, CEF + FM vs. control) confirm findings of other studies, demonstrating that the acute phase proteins are valuable indicators for acute inflammatory processes (Alsemgeest et al., 1994; Smith et al., 1998; Schonfelder et al., 2005). Elevated $\mathrm{Hp}$ and $\mathrm{Fb}$ concentrations at $\mathrm{d} 0$ in control cows can be explained by mild inflammatory processes occurring physiologically during parturition. Schonfelder et al. (2005) found an increase in Hp from 0.009 to $0.8 \mathrm{mg} /$ $\mathrm{mL}$ from calving to $\mathrm{d} 10 \mathrm{in}$ cows with spontaneous delivery and from 0.1 to $1.8 \mathrm{mg} / \mathrm{mL}$ in cows with caesarean section. In our study, mean $\mathrm{Hp}$ concentration in groups $\mathrm{CEF}$ and $\mathrm{CEF}+\mathrm{FM}$ during the first $10 \mathrm{~d}$ after calving was in the range of cows with caesarean section, whereas $\mathrm{Hp}$ in control cows were comparable to cows with spontaneous parturition in the cited study. As in the study by Smith et al. (1998), concentrations of $\mathrm{Hp}$ decreased in APM cows after an antibiotic treatment. Concentrations of $\mathrm{Hp}$ and $\mathrm{Fb}$ decreased in $\mathrm{CEF}, \mathrm{CEF}$ + FM, and in control cows. Therefore, it cannot be concluded that the decrease in concentrations of $\mathrm{Hp}$ and $\mathrm{Fb}$ in APM cows was an effect of the antibiotic treatment. The additional treatment with FM did not show any additional beneficial effects.

Because of the life-threatening character of APM, the owner of the commercial dairy farm refused to include an untreated control group (i.e., not treated with antibiotics). Therefore, further study is needed to determine if the systemic antibiotic treatment, which has been described in several studies on APM (Smith et al., 1998; Drillich et al., 2001, 2006), has concealed possible positive effects of the antiinflammatory treatment.

\section{CONCLUSION}

The rationale for the treatment with FM was the hypothesis that NSAID should restrict inflammatory processes in the uterine wall, followed by improved cure rates and increased reproductive performance. The results of our study clearly reject this hypothesis. Further research is required to evaluate the effect of different treatment regimes with NSAID (e.g., prolonged treatment or long-acting NSAID) on clinical cure rates and reproductive performance of cows with APM.

\section{ACKNOWLEDGMENTS}

We acknowledge the cooperation with Essex Tierarznei, Munich, Germany.

\section{REFERENCES}

Alsemgeest, S. P., H. C. Kalsbeek, T. Wensing, J. P. Koeman, A. M. van Ederen, and E. Gruys. 1994. Concentrations of serum amyloid-A (SAA) and haptoglobin (Hp) as parameters of inflammatory diseases in cattle. Vet. Q. 16:21-23.

Amiridis, G. S., L. Leontides, E. Tassos, P. Kostoulas, and G. C. Fthenakis. 2001. Flunixin meglumine accelerates uterine involution and shortens the calving-to-first-oestrus interval in cows with puerperal metritis. J. Vet. Pharmacol. Ther. 24:365-367.

Baumann, H., and J. Gauldie. 1994. The acute phase response. Immunol. Today 15:74-80.

Cheryk, L. A., K. E. Hooper-McGrevy, and P. A. Gentry. 1998. Alterations in bovine platelet function and acute phase proteins induced by Pasteurella haemolytica A1. Can. J. Vet. Res. 62:1-8.

Dinsmore, R. P., R. D. Stevens, M. B. Cattell, M. D. Salman, and S. F. Sundlof. 1996. Oxytetracycline residues in milk after intrauterine treatment of cows with retained fetal membranes. J Am. Vet. Med. Assoc. 209:1753-1755.

Drillich, M., O. Beetz, A. Pfutzner, M. Sabin, H. J. Sabin, P. Kutzer, H. Nattermann, and W. Heuwieser. 2001. Evaluation of a systemic antibiotic treatment of toxic puerperal metritis in dairy cows. J. Dairy Sci. 84:2010-2017.

Drillich, M., M. Mahlstedt, U. Reichert, B. A. Tenhagen, and W. Heuwieser. 2006. Strategies to improve the therapy of retained fetal membranes in dairy cows. J. Dairy Sci. 89:627-635.

Drillich, M., A. Pfutzner, H. J. Sabin, M. Sabin, and W. Heuwieser. 2003. Comparison of two protocols for the treatment of retained fetal membranes in dairy cattle. Theriogenology 59:951-960.

Eiler, H. 1997. Retained placenta. Pages 340-348 in Current Therapy in Large Animal Theriogenology. R. S. Youngquist, ed. W. B. Saunders Co., Philadelphia, PA.

Friton, G. M., C. Cajal, R. Ramirez Romero, and R. Kleemann. 2004 Clinical efficacy of meloxicam (Metacam) and flunixin (Finadyne) as adjuncts to antibacterial treatment of respiratory disease in fattening cattle. Berl. Munch. Tierarztl. Wochenschr. 7-8:304309.

Hirvonen, J., G. Huscenicza, M. Kulcsar, and S. Pyörälä. 1999. Acute phase response in dairy cows with acute postpartum metritis. Theriogenology 51:1071-1083.

Königsson, K., H. Gustafsson, A. Gunnarsson, and H. Kindahl. 2001. Clinical and bacteriological aspects on the use of tetracycline and flunixin in primiparous cows with induced retained placenta and post-partal endometritis. Reprod. Domest. Anim. 36:247-256.

Montes, A. J., and D. G. Pugh. 1993. Clinical approach to postpartum metritis. Compend. Contin. Educ. Pract. Vet. 15:1131-1147.

Nakao, T., A. Gamal, T. Osawa, K. Nakada, M. Moriyoshi, and K. Kawata. 1997. Postpartum plasma PGF metabolite profile in cows with dystocia and/or retained placenta, and effect of fenprostalene on uterine involution and reproductive performance. J. Vet. Med. Sci. 59:791-794.

Odensvik, K., and G. Fredriksson. 1993. The effect of intensive flunixin treatment during the postpartum period in the bovine. Zentralbl. Veterinarmed. A 40:561-568.

Rajala, P. J., and Y. T. Gröhn. 1998. Effects of dystocia, retained placenta, and metritis on milk yield in diary cows. J. Dairy Sci. 81:3172-3181.

Schonfelder, A., W. Schrodl, M. Kruger, A. Richter, and A. Sobiraj. 2005 . The change of acute phase protein haptoglobin in cattle during spontaneous labor and Caesarean section with or without torsio uteri intrapartum. Berl. Munch. Tierarztl. Wochenschr. 118:240-246.

Sheldon, I. M., G. S. Lewis, S. LeBlanc, and R. O. Gilbert. 2006. Defining postpartum uterine disease in cattle. Theriogenology 65:1516-1530. 
Sheldon, I. M., D. E. Noakes, A. Rycroft, and H. Dobson. 2001. Acute phase protein responses to uterine bacterial contamination in cattle after calving. Vet. Rec. 148:172-175.

Smith, B. I., G. A. Donovan, C. Risco, R. Littell, C. Young, L. H. Stanker, and J. Elliott. 1998. Comparison of various antibiotic treatments for cows diagnosed with toxic puerperal metritis. J. Dairy Sci. 81:1555-1562.

Stevens, R. D., R. P. Dinsmore, and M. B. Cattell. 1995. Evaluation of the use of intrauterine infusions of oxytetracycline, subcutaneous injections of fenprostalene, or a combination of both, for the treatment of retained fetal membranes in dairy cows. J. Am. Vet. Med. Assoc. 207:1612-1615.

Tenhagen, B. A., D. Edinger, and W. Heuwieser. 1999. Impact of dystocia in primiparous cows on lactational performance and survival. Tierarztl. Umsch. 54:617-623.

Zhou, C., J. F. Boucher, K. J. Dame, M. Moreira, R. Graham, J. Nantel, S. Zuidhof, L. Arfi, R. Flores, G. Neubauer, and J. Olson. 2001. Multilocation trial of ceftiofur for treatment of postpartum cows with fever. J. Am. Vet. Med. Assoc. 219:805-808. 